DOI: 10.14526/2070-4798-2019-14-3-30-34

\title{
Practical substantiation of the ways of general and specific coordination abilities development in students-badminton players taking into account nervous system characteristics
}

\author{
Yuliya K. Zhestkova*, Irina G. Gerasimova, Rail Kh. Bekmansurov, Raziya F. Akhtariyeva \\ Yelabuga institute (branch) of Kazan (Volga) Federal University \\ Yelabuga, Russia \\ ORCID: oooo-0003-7622, zhest.13@list.ru* \\ ORCID: 0000-0002-6990-0184, irina-chelny74@mail.ru \\ ORCID: oooo- 002-63348-6656, Rail.bek @mail.ru \\ ORCID: oooo-0oo2-7423-7671, razia-a @yandex.ru
}

\begin{abstract}
The article is about theoretical and practical aspects of specific coordinating abilities development in students-badminton players, taking into consideration the characteristics of nervous system. Sports games, especially badminton, were included into the program of training students at higher educational establishments. Wide use of all sports games in physical culture and sport life of students at higher educational establishments helps to create fundamental base for health potential formation for the future professional activity. In this connection it is important to pay special attention to the opportunity of developing competitive activity among students-badminton players, owing to high level of coordinating potential of playing badminton formation. Materials. The work analyzed modern tendencies of badminton development among students. Short characteristic of important coordinating abilities is given, which are defined by students-badminton players themselves. Research methods. Scientific-methodical sources study. A questionnaire survey in students-badminton players connected with the questions of significant coordinating abilities for badminton players. In order to study students' nervous system characteristics we used activatiometer "ATS-9K". Results. We gave the characteristic of competitive activity in badminton. We held a questionnaire survey among students-badminton players concerning the questions of significant general and specific coordinating abilities revelation. We revealed and estimated significance of badminton players' coordinating abilities according to pint system. Diagnosing the power and weakness of nervous system among studentsbadminton players helped to prove the effectiveness of taking into account strong sides and weaknesses of nervous system among students-badminton players in planning training means and loads. Such kind of approach helps to increase the effectiveness of coordinating abilities development of general and specific character. Conclusion. Taking into account strong and weak sides of nervous system among badminton players helps to select necessary means for coordinating abilities development, as the basis for competitive activity effectiveness increase.

Keywords: students, badminton, competitive activity, strength and weakness of a nervous system, coordination abilities, reacting abilities.
\end{abstract}

For citation: Yuliya K. Zhestkova*, Irina G. Gerasimova, Rail Kh. Bekmansurov, Raziya F. Akhtariyeva. Practical substantiation of the ways of general and specific coordination abilities development among students-badminton players taking into account nervous system characteristics. Russian Journal of Physical Education and Sport. 2019; 14(3): 30-34. DOI: 10.14526/2070-4798-2019-14-3-30-34

\section{INTRODUCTION}

Modern competitive activity among studentsbadminton players demands effectiveness of performances increase owing to technical and physical-functional and psychological training development. Badminton is a sports game, a kind of motor activity in a form of difficult coordinating playing exercise, directed toward speed, accuracy, flexibility, coordinating and functional abilities demonstration in a sub-maximal zone of power. Badminton game can last for a long time period, be tense and extreme depending on badminton players' training level [1]. Characterizing the main tendencies of modern badminton development, we can mention that this kind of sport develops owing to the following thing development: tactical system in game; mobility and universal character of strike and speed of shuttlecocks exchange; speed combinations of pass and strike into a shuttlecock; playing activity organization; quick actions switching.

Competitive activity of badminton players is also characterized by the increased activity of players, partners, opponents, not only owing to technicality, but owing to tactical character of 
movements. The number of players' actions in a unit of time increased owing to speed of coordinating movements increase. We see players' physical and functional readiness improvement. For further performances effectiveness improvement among students-badminton players it is necessary to create different innovative methodologies, taking into account the specificity of this kind of sport.

Taking into account nervous system characteristics of students-badminton players helps to select timely necessary means for coordinating abilities development, as the base for competitive activity increase among students.

In some works specialists mention significance of different physical culture and sport innovative directions influence on physical and psychic health of students.

S. Boychenko and others (2002) consider the peculiarities of complex coordinating abilities demonstration, as the base for competitive activity effectiveness increase in sports games [2].

E.V. Bulanova and others (2019) study the influence of different physical culture means on psychophysiological characteristics of students, mentioning that traditional lessons influence central nervous system indices, but don't improve cognitive indices. They offer to pay special attention to using problem based tasks for thinking improvement [3].

F.G. Valeev, (1998) studies playing badminton effectiveness improvement, taking into account lability of nervous system [4].

Y.M. Valkin (2008) mentions the necessity to control the dynamics of accuracy of movements among male 17-19 year-old badminton players [5].

V.I. Karpenko (2005) in the methodology of an individual approach realization directs speed-power oriented qualities development among badminton players [6].

R.F. Kusyakova (2014) pays special attention coordinating abilities development by means of classical dancing, as an effective means of physical readiness increase among students $[7,8]$.

In works of O.V. Kudimova (2002) the methodology of estimating the quality of passes and attacking strikes in badminton, where the significance of physical qualities development is mentioned, is presented [9].

It is important to pay attention to students' physical readiness effectiveness increase by means of badminton, which forms the complex of necessary physical qualities development. It should be noted that this index helps to individualize means use, taking into account nervous system characteristics of each student. Dividing students according to the power and weakness of nervous system helps to correct timely badminton players' specific coordinating abilities development. It is known that a powerful nervous system is typical for an enduring person, who can stand physical load for a long time period. For a person with a weak nervous system it is necessary to correct the load during sports training using block system of training loads realization. As some people fulfill training tasks quicker and some slower. In practice both types of nervous system have the right for success.

\section{MATERIALS AND METHODS}

Scientific-methodical sources study. A questionnaire survey among students-badminton players connected with the questions of significant coordinating abilities for badminton players. In order to study students' nervous system characteristics we used activatiometer "ATS-9K". The following indices were analyzed: accuracy of reaction to a moving object (ARMO); coefficient of power and weakness of nervous system (CpNS); coefficient of number of movements (NumM); coefficient of sense of tempo (CST). Results interpretation was realized taking into account the intensity of power and weakness of nervous system in students-badminton players. The research was held in students of the 2nd and the 3 rd courses of Yelabuga institute, who train at sportsmanship improvement groups.

\section{RESULTS AND DISCUSSION}

Badminton includes such specific qualities as a high level of pass accuracy and shuttlecock taking, speed of motor actions fulfillment, quick space orientation in playing actions; high level of coordination of movements in changing situations of the game, connected with opponent's movement and strikes fulfillment from different positions. That is why badminton players need high level of attention, coordinating abilities, nervous processes flexibility and muscle efforts differentiation.

Questionnaire survey held among badminton players (candidate masters, masters of sport) in the group of sportsmanship improvement helped to reveal significant for them coordinating abilities of badminton players.

The first place was given to the ability to orient oneself in space. The second place was given to the ability to preserve balance and movement transformation. Regardless of the fact that specialists consider reacting ability important for badminton players, respondents gave it only the third place. It is connected with the fact that the reacting ability is mainly developed at the initial stage of teaching badminton [10].

In the works of the authors less attention is paid to coordinating abilities development among badminton players, taking into account power and weakness of nervous system.

We diagnosed power and weakness of nervous system in students-badminton players, who train according to a traditional program of training, and students-badminton players, who train including into the program of training the experimental 
methodology. The reacting ability of badminton players demands special control, as in our opinion, it will provide general and specific regulating abilities development in badminton players. If the training tasks are distributed taking into account power and weakness of nervous system characteristics in students, it has a great influence on competitive

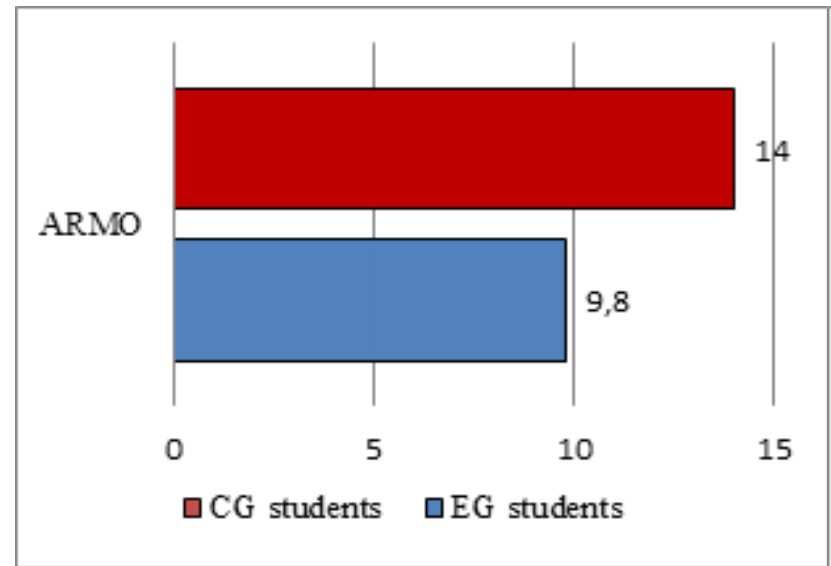

Fig.1. Accuracy of reaction indices to a moving object in students badminton players (conditional units)

Students, who had additional complex of exercises during the training lessons, directed toward coordinating abilities development, had higher values of ARMO (14 c.u.), than studentsbadminton players of the control group ( 9,8 c.u.).

Students badminton players from EG had a very high level of coefficient of nervous system power, which was $43 \%$ with plus sign, defining a very high level of nervous system power increase. In students badminton players from the CG the level of coefficient of nervous system power was $20 \%$ with minus sign, defining the average level of nervous system weakness intensity.

Thus, students from EG have working capacity stability increase against physical loads. Students from CG have distinct inhibitory processes of nervous system, as a result of tiredness and a low level of physical readiness. activity effectiveness.

Picture 1 and 2 present accuracy of reaction indices to a moving object and coefficient of power and weakness of nervous system among studentsbadminton players according to the results of testing at ativatiometer.

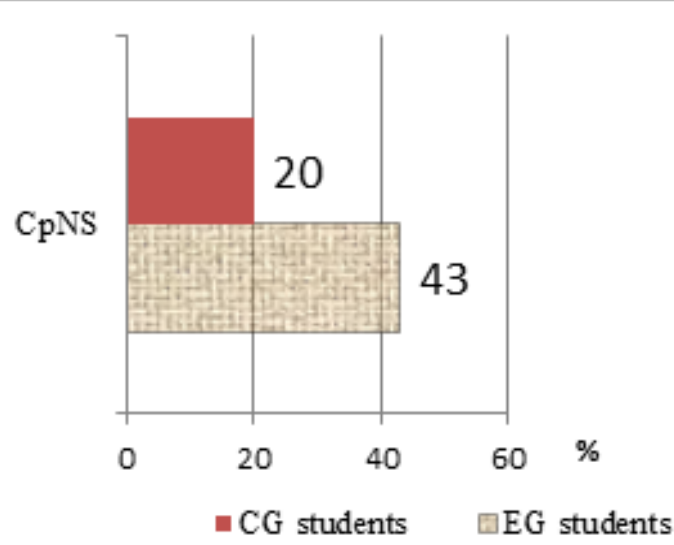

Fig. 2. Indices of coefficient of power and weakness of nervous system in students-badminton players

The indices of the number of the fulfilled movements are high among EG students, at the beginning the increase was $30,8 \%$, to the end of the first stage of the research the increase was $41,34 \%$. In CG the results of students- badminton players turned out to be not high 29,6\% and 31,45\%.

The coefficient of the sense of tempo is the index, which characterizes the features of badminton players nervous system (Picture 2). Among students badminton players from EG the coefficient of the tempo sense (CST) was1,75 $\pm 0,30$ c.u., at the end

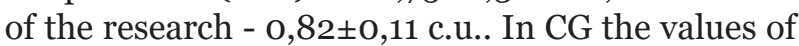
CST stayed lower than the average level and were 2,01 $\pm 0,31$ c.u. and $1,98 \pm 0,41$ c.u..

Thus, in the EG there is the level of training loads and rest control, taking into account the characteristics of nervous system.

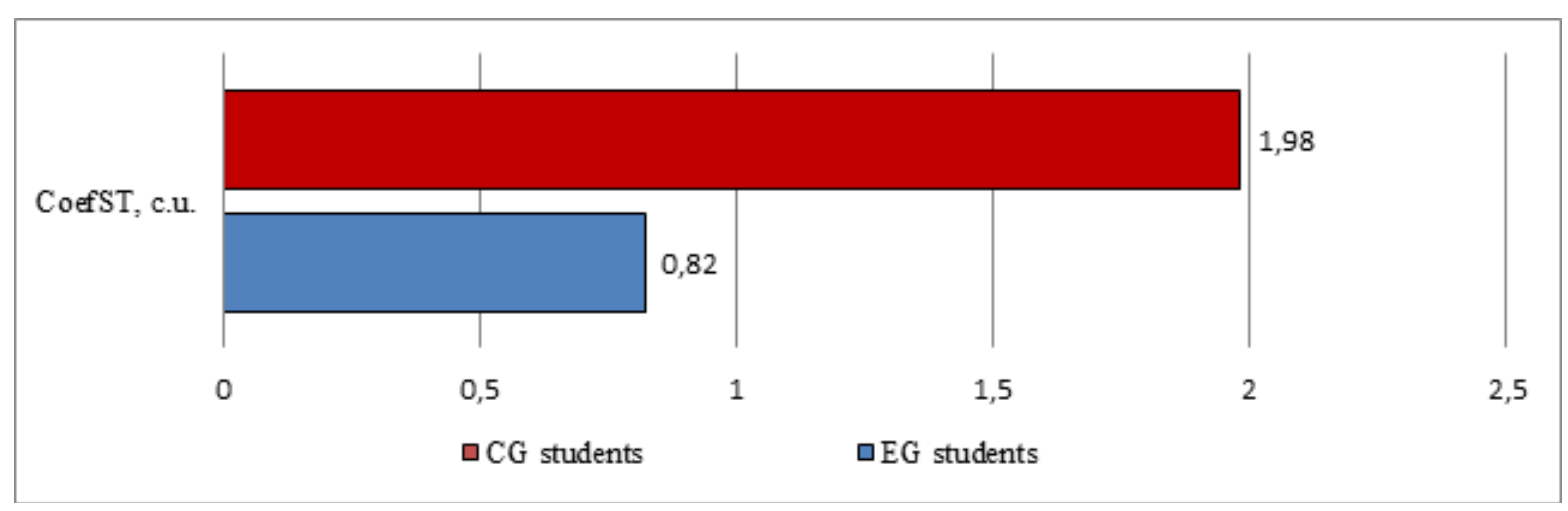

Fig. 3.The indices of CST in students- badminton players, (c.u.) 
The indices of nervous system power and weakness in students- badminton players also help to realize competent selection of students for taking part in competitions, taking into account physical, functional and psychological readiness and sports activity effectiveness.

Then we realized the analysis of the reacting ability level demonstration in students- badminton players. For its characteristic we used the time of reaction to the sound and light, reaction to a moving object, time of choice reaction and test with falling ruler catching. And for specific reacting ability characteristic of students badminton players we used testing exercises, kinds of juggling with foam balls and a shuttlecock within 15 and 30 seconds in the number of times. Test exercise of juggling with shuttlecock for maximum quantity was used.

In the EG there was considerable indices change in the testing exercises, than in the CG. For example, time of reaction to the sound and light was 0,43 and 0,31 seconds in the EG and 0,42 and 0,40 seconds in the $\mathrm{CG}$.

Specific reacting abilities turned out to be higher among EG students.

Juggling with foam balls and a shuttlecock within 15 seconds among EG students was 16,1 13,2 and $17,9 \pm 4,2$ times, in CG $-12,7 \pm 2,9$ and $15,3 \pm 4,1$ times.

Juggling with a shuttlecock is considered a difficult exercise, directed toward the reacting ability 7 revelation among badminton players. In the EG this index was 21,3 times within 30 seconds, in the CG - 15,3 times within 30 seconds. At the second stage of the research in the EG this index was 29,3 times and 17,4 times among students- badminton players from the $\mathrm{CG}$.

\section{CONCLUSION}

For further development of badminton players' performances effectiveness during the competitions it is necessary to individualize the methodology of training not only taking into account the specificity of the kind of sport, but also taking into account the typology of nervous system features.

It was mentioned that taking into account nervous system characteristics in studentsbadminton players helps to select necessary means for coordinating abilities development, as the base for competitive activity effectiveness improvement.

The results of power and weakness of nervous system diagnostics in students -badminton players, who train according to traditional program and students, who pay great attention to coordinating abilities development, in particular the reacting ability, showed that the latter had the advantage over the first group of students.

Thus, general and specific reacting abilities of badminton players demand special control for coordinating abilities development in general.
Power and weakness of nervous system characteristic diagnostics helps to correct the training loads and individualize training means selection.

\section{REFERENCES}

1. Badminton: primernaya programma sportivnoj podgotovki dlya DYUSSH, SDYUSHOR, UOR I SHVSM [Badminton: model program of sports training for sports schools for children and teen-agers, sports schools for children and teenagers of the Olympic reserve]. Moscow: Soviet sport. 2010: 160 .

2. Boychenko S., Voynar Yu., Smotritskiy A. Peculiarities of complex (hybrid) coordinating abilities demonstration among the representatives of sports games. Physical education and sport. 2002; 46: 313-314 (In Engl.).

3. Bulanova E.V., Osipova B.G., Korshunova L.A., Lebedeva E.A. The influence of different physical culture means on cognitive and psychomotor indices of medical University students. Pedagogikopsihologicheskie I medico-biologicheskie problemy fizicheskoj kul'tury I sporta = Russian Journal of Physical Education and Sport. 2019; 14(2): 38-42. DOI: 10.14526/2070-4798-2019-14-2-38-42. (In Russ., In Engl.)

4. Valeev F. G. Sport characteristics increase of the games in badminton taking into account nervous system lability. Candidate's thesis. Moscow: 1998: 24

5. Valki Yu. M., Klyuchnikova S.N. The dynamics of accuracy of movements control among 17-19 year-old boys-badminton. Teoriya I praktika fizicheskoj kul'tury: zhurnal v zhurnale. 2008; 2: 47-48 (In Russ.).

6. Karpenko V. I. Methodology of individual approach realization in speed-power qualities development among badminton players. Problemy sovershenstvovaniya fizicheskoj kul'tury, sporta I Olimpizma v Sibiri: materialy Vserossijskoj nauchno-prakticheskoj konferencii molodyh uchenyh [Problems of physical culture, sports and Olympic direction development in Siberia: materials of All-Russian scientific-practical conference of young scientists]. Federal agency of physical culture and sport, Siberian State University of Physical Culture and Sport, Siberian Olympic Academy. Omsk. 2005: 74-76.

7. Kusyakova R.F. Coordinating abilities development among students by means of classical dancing. "Days of science - 2014": materials of the International scientific-practical conference. Czechia, 2014: 27-29 (In Engl.).

8. Kusyakova R.F. Effectiveness of classical dancing means use for students' coordinating abilities development at physical culture lessons. Sovremennye problem I perspektivy razvitiya fizicheskoj kul'tury, sporta, turizma I social'no- 
kul'turnogo servisa: materialy II Vserossijskoj (s mezhdunarodnym uchastiem) nauchnoprakticheskoj konferencii [Modern problems and perspectives of physical culture, sport, tourism and social-cultural service development: materials of the II All-Russian (with International participation) scientific- practical conference]. Naberezhnye Chelny: Publishing house of Povolzhskaya State Academy of Physical Culture, Sport and Tourism. 2014: 142-144.

9. Kudimova O. V. Methodology of quality of passes and attacking strikes estimationin badminton. Sportivnye igry v fizicheskom vospitanii I sporte: materialy mezhdunarodnoj nauchno-prakticheskoj konferencii (Smolensk, 24-26 dekabrya 2002 goda) [Sports games in physical upbringing and sport: materials of the International scientific-practical conference (Smolensk, December, 24-26, 2002)]. Smolensk. 2002: 318-362.

10. Martynova A.S., Ivanova E.V. Coordinating abilities and psychic functions development among 8-13 year-old badminton players. Aktual'nye problem fizicheskoj kul'tury I sporta v usloviyah modernizacii vysshej shkoly: sbornik materialov Vserossijskoj nauchno-prakticheskoj konferencii [Urgent problems of physical culture and sport in terms of higher school modernization: collection of materials of All-Russian scientific-practical conference]. Chelyabinsk: Ural State Academy of Physical Culture. 2007: 110-112.

11. Bourbousson, J., Seve, \& McGarry, T. Space time coordination dinamics in basketball: Part 1. Intra- and inter coupling among player dyads. Journal of Sports Sciences. 2010a; 28: 339-347.

12. Correa, V., Araujo, D., C., \& Passos, P. Prospective information for pass decisional behavior in rugby union. Human Movement Science. 2011; 30: $984-997$.

13. Eccles, D., W., \& Tenenbaum, G. Why an expert team is more than a team of experts: A cosial cognitive conceptualization of team coordination and communication in sport. Journal of Sport and Exercise Psychology. 2004; 26: 542-560.

\section{Submitted: 29.08.2019}

Author's information:

Yuliya K. Zhestkova - Senior Lecturer, Elabuga Institute (branch) of Kazan (Volga) Federal University, 42360o, Russia, Elabuga, Kazanskaya str., House 89, e-mail: zhest.13@list.ru

Irina G. Gerasimova - Candidate of Pedagogics, Elabuga Institute (branch) of Kazan (Volga) Federal University, 423600, Russia, Elabuga, Kazanskaya str., House 89, e-mail: irina-chelny74@mail.ru

Rail Kh. Bekmansurov - Senior Lecturer, Elabuga Institute (branch) of Kazan (Volga) Federal University, 423600, Russia, Elabuga, Kazanskaya str., House 89, e-mail: Rail.bek@mail.ru

Raziya F. Akhtariyeva - Candidate of Pedagogics, Associate Professor, Elabuga Institute (branch) of Kazan (Volga) Federal University, 42360o, Russia, Elabuga, Kazanskaya str., House 89, e-mail: razia-a@ mail.ru 